\title{
Effects of waste cotton usage on properties of OE-rotor yarns and knitted fabrics
}

DOI: $10.35530 / I T .070 .03 .1560$

MUSA KILIC

GONCA BALCI KILIC

H. KÜBRA KAYNAK

EFLATUN TIRYAKI

MURAT DEMIR

\section{REZUMAT - ABSTRACT}

Efectele utilizării deșeurilor de bumbac asupra proprietăților firelor filate cu rotor OE și ale materialelor tricotate

Utilizarea materialelor reciclate a câștigat o importanță masivă atât în sectorul textil, precum și în alte sectoare, deoarece efectele reducerii surselor naturale sunt resimțite peste tot în lume. În acest studiu, s-a urmărit analizarea efectelor utilizării bumbacului reciclat asupra proprietăților firelor filate cu rotor OE și a tricoturilor realizate din aceste fire. În acest scop, firele filate cu rotor $O E$ au fost produse în diferite amestecuri de bumbac virgin și deșeuri de bumbac care provin din bataj, în proporție de 25\%, 50\%, 75\%, și respectiv 100\%. Pentru o evaluare mai bună, proprietățile firelor filate cu rotor OE care conțin deșeuri de bumbac au fost comparate cu firele filate cu rotor OE din bumbac virgin. Proprietățile fizice, structurale și mecanice, cum ar fi neuniformitatea, imperfecțiunile, pilozitatea, forța de rupere, alungirea, frecarea fir-fir, frecarea fir-metal și frecarea fir-ceramică, au fost măsurate cu Uster Tester 4 SX, Uster Zweigle Hairiness Tester 5, Uster Tensorapid 3 și CTT Lawson Hemphill. În cea de-a doua parte a studiului, au fost realizate tricoturi glat din firele filate cu rotor OE. Au fost evaluate, de asemenea, efectele ponderii deșeurilor reciclate asupra proprietăților țesăturii tricotate, cum ar fi pilingul, rezistența la abraziune, rezistența la plesnire și permeabilitatea la aer. Rezultatele au arătat că utilizarea a până la $75 \%$ în amestec a bumbacului reciclat nu prezintă diferențe semnificative din punct de vedere statistic în ceea ce privește proprietățile firelor și țesăturilor.

Cuvinte-cheie: bumbac reciclat, deșeuri de bumbac, filare cu rotor OE, fire în amestec, proces sustenabil de producție

\section{Effects of waste cotton usage on properties of OE-rotor yarns and knitted fabric}

The use of recycled materials has gained massive importance in textile sector as well as in other sectors as the effects of reduction of natural sources are felt all over the world. In this study, it was aimed to analyse the effects of recycled cotton usage on properties of OE-rotor spun yarns and knitted fabrics produced from these yarns. For this purpose, OE-rotor yarns were produced at different proportion levels of virgin cotton and waste cotton that derived from blowroom $25 \%, 50 \%$, $75 \%, 100 \%$, respectively. For better assessment, properties of OE-rotor yarns that contain waste cotton were compared with $100 \%$ virgin cotton OE rotor yarn. Physical, structural and mechanical properties such as unevenness, imperfections, hairiness, breaking force, elongation, yarn-to-yarn friction, yarn-to-metal friction and yarn-to-ceramic friction were measured by Uster Tester 4 SX, Uster Zweigle Hairiness Tester 5, Uster Tensorapid 3 and CTT by Lawson Hemphill. At the second part of the study, single-jersey knitted fabrics were produced from OE-rotor spun yarns. Effects of waste cotton proportion on knitted fabric properties such as pilling, abrasion resistance, bursting strength and air permeability were also evaluated. Results showed that, the use of up to $75 \%$ per cent of waste cotton blended yarns show no statistically significant differences on yarn and fabric properties.

Keywords: recycled cotton, waste cotton, OE-rotor spinning, blended yarns, sustainable production process

\section{INTRODUCTION}

Textile industry is one of the major sectors that scope all over the world and consumption level of textile products have been rising year by year as a consequence of growth of the world population and improvements of living standards [1]. Cotton keeps its position as a main raw material for textile industry despite of recent improvements of synthetic and regenerated fibres [2]. The other point of view, production level of cotton has been fluctuated for recent years, and because of strict relation with geographical condition, it is hard to estimate production level of cotton for upcoming years [3].
By the relation with cotton position in textile industry, efficient waste management plays major role for cost of textile product. In order to reduce production costs and obtain sustainable and ecological production processes as well as to prevent harmful effects of cotton farming such as release of carbon dioxide, water and energy consumption, many multinational textile suppliers begin to use recycled or waste cotton [4-6]. With the rising concern of global warming and reduces of natural sources, some protocols i.e. Kyoto and Montreal are put into effect in order to protect environment and prevent release of greenhouse gases. Moreover, international organisations such as Global Organic Textile Standard (GOTS), Better 
Cotton Iniative $(\mathrm{BCl}), e^{3}$ Sustainably Grown Cotton, Cotton Leads focus on sustainable production process of textile products as well as provide cotton farming in better ecologic environment. On the other hand, products that produced from recycled materials find position between many consumers' first consumption choices and create their own market share known as "green market" or "environmental marketing" [7].

In the literature, it is seen that many researchers produced open-end rotor spun yarns by using recycled cotton. It can be related with the reason of capability of rotor spun technology to produce yarn from cotton waste at high twist level unlike other spinning technologies. Hassani et al. investigated the optimum spinning conditions for rotor spun yarns that different proportional cotton wastes derived from ginning machines blended with secondary raw material [8]. Khan et al. studied on the prediction of the properties of cotton/waste blended OE rotor spun yarns using Taguchi OA design [9]. They concluded that the proportion amount of waste cotton is the most influential parameter on the properties of cotton/waste blended yarns. Taher et al. analysed the influence of spinning parameters and recover fibres from cotton waste on the uniformity and hairiness of rotor spun yarns [10]. They indicated that yarn count, rotor parameters such as diameter, form and rotor speed have considerable effects as much as waste proportion. Furthermore, they also denoted that using $25 \%$ of recycle fibre does not change the uniformity and appearance of rotor spun yarn in their study. Halimi et al. also examined the effect of cotton waste and spinning parameters on the rotor yarn quality [11]. Results of their study also verified that up to between $15 \%$ and $25 \%$ cotton waste ratio does not cause any change on rotor yarn quality with the optimum spinning parameters. Hassani and Tabatabei focused on optimising of spinning variables in order to reduce hairiness of rotor yarn produced from waste fibres that collected from ginning process [12]. According to conclusions of study, rotor diameter and navel type have significantly higher effect than other production parameters on the hairiness of rotor spun yarn with all proportion levels $(65 \%, 50 \%, 35 \%)$ of waste cotton. Halimi et al. investigated proportion of good fibres inside cotton wastes that derived from blow room and card machines using both of the qualitative and quantitative methods [13]. In order to determine cotton wastes as a good fibre, OE rotor yarns produced and analysed. Results showed that between $15 \%$ and $25 \%$ cotton wastes can be blended with virgin cottons without noticeable drawbacks on rotor yarn quality. Celep et al. presented an experimental study on the thermal comfort properties of single jersey knitted fabrics that produced from $100 \%$ virgin cotton, $\% 100$ recycled cotton, $50 \%-50 \%$ recycled-virgin cotton OE yarns [14]. Regarding the comparative analysis between samples, it is seen that thermal conductivity, thermal absorptivity, air permeability decreased and thermal resistance increased with the increased proportion of recycled cotton fibres. Vadicherla and Saravanan were also studied thermal comfort properties of single jersey knitted fabrics that contain different ratios of recycled polyester and cotton blended yarns [15]. It was seen from their study that fabrics become thinner, lighter, more porous with higher thermal conductivity, air permeability and less thermal resistance with increasing ratio of recycled polyester.

Aim of this study is to investigate how cotton waste proportion effects yarn and fabric quality and propose an optimum blend ratio for effective waste management. For this purpose, OE-rotor spun yarns were produced at different proportions of virgin and waste cotton that was obtained from blow-room and single jersey knitted fabrics were also produced from all yarn types.

\section{EXPERIMENTAL}

In this study, Ne 22/1 OE-rotor yarns with $\alpha_{e}=4.2$ twist level were produced from $100 \%$ virgin cotton, $100 \%$ waste cotton and virgin-waste cotton blends (75\%-25\%,50\%-50\% and $25 \%-75 \%$ ). Turkish cotton was used as virgin cotton and waste cotton was obtained from blowroom. HVI values of Turkish cotton are shown in table 1.

\begin{tabular}{|c|c|}
\hline \multicolumn{2}{|c|}{ Table 1 } \\
\hline \multicolumn{2}{|c|}{ HVI VALUES OF VIRGIN COTTON } \\
\hline Property & Value \\
\hline Micronaire (mg/inch) & 4.29 \\
\hline Maturity & 0.88 \\
\hline Length (mm) & 28.56 \\
\hline Uniformity (\%) & 82 \\
\hline Short Fibre Index (SFI) & 8.0 \\
\hline Strength (cN/tex) & 32.1 \\
\hline Elongation (\%) & 7.5 \\
\hline
\end{tabular}

Ne 0.12 slivers were produced after two drawframe passages. In OE-rotor yarn production, rotor and opening roller revolutions were 95000 and $8600 \mathrm{rpm}$, respectively. Physical, structural and mechanical properties of these yarns were measured by Uster Tester 4 SX, Uster Zweigle Hairiness Tester 5, Uster Tensorapid 3 and Lawson Hemphill CTT.

At the second part of the study, single-jersey knitted fabrics were produced from OE-rotor yarns. Effects of waste cotton proportion on knitted fabric properties such as pilling, abrasion resistance, bursting strength and air permeability were also evaluated. Abrasion resistance and pilling tendency tests were performed using James $\mathrm{H}$. Heal Nu-Martindale Abrasion and Pilling Tester. The weight losses ( $\%$ and $\mathrm{mg}$ ) and changes of thickness (\% and $\mathrm{mm}$ ) of the samples were calculated at the end of 15000 cycles to measure the abrasion resistance of the fabrics. Pilling tendencies of fabrics were determined in accordance 
with ISO 12945:2. In this method, ratings for tested samples were determined by comparing with standard photographs. " 5 " rating shows that there is no visible change on the surface of the fabric. Bursting strength tests were performed by James $\mathrm{H}$. Heal TruBurst Bursting Strength Tester by using $7.3 \mathrm{~cm}^{2}$ test area according to ASTM D3786/D3786M-13. Air permeability values of fabrics were measured in accordance with ISO 9237 using $20 \mathrm{~cm}^{2}$ test area and $100 \mathrm{~Pa}$ test pressure.

\section{RESULTS AND DISCUSSION}

\section{Evaluation of yarn properties}

For a better understanding of how usage of waste cotton affects quality of OE-rotor spun yarns, properties such as unevenness, imperfections, hairiness, breaking force, breaking elongation and friction (yarn-to-yarn, yarn-to-metal and yarn-to-ceramic) were analysed statistically using ANOVA and confidence interval graphs at $95 \%$ confidence level.

\section{Unevenness}

Figure 1 shows the effect of waste cotton proportion on yarn unevenness. Unevenness and proportion of waste cotton show parallel increase due to the increasing amount of short fibre in the yarn. Moreover, there is no statistically significant difference amongst the blended yarns up to $75 \%$ waste content.

Table 2 shows the ANOVA results and table 3 shows the pairwise comparisons of the yarn types. As it is indicated in table 2, waste cotton usage is statistically significant on yarn unevenness $(p=0.007)$. Moreover, results in table 3 shows that there is no

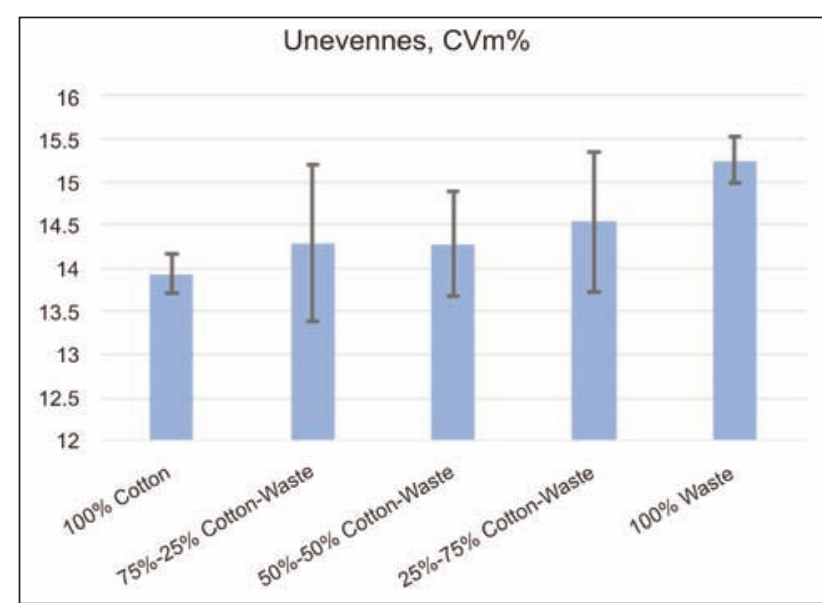

Fig. 1. Unevenness (CVm\%) values and 95\% confidence intervals

statistically significant difference between 100\% cotton, $75 \%-25 \%, 50 \%-50 \%$ and $25 \%-75 \%$ cotton-waste yarns. Only $100 \%$ cotton waste yarns show statistically significant difference with other yarn types $(p<0.05)$.

\section{Imperfections}

The effects of waste cotton proportion on imperfections are illustrated in figure 2. As it is seen from the figure, the number of thin places and thick places which are more likely related with drafting system do not show statistically significant difference regarding the proportion of waste cotton. Comparing neps values shows that $100 \%$ waste cotton have the greatest value and it might be related with amount of immature cotton fibres in yarn structure.

\begin{tabular}{|c|c|c|c|c|c|}
\hline \multicolumn{7}{|c|}{ ANOVA RESULTS FOR UNEVENNESS (CVM\%) VALUES } \\
\hline Source & Type III Sum of Squares & df & Mean Square & F & Sig. \\
\hline Corrected Model & $4.847^{\mathrm{a}}$ & 4 & 1.212 & 4.754 & .007 \\
\hline Intercept & 5225.460 & 1 & 5225.460 & 20499.087 & .000 \\
\hline Yarn Type & 4.847 & 4 & $\mathbf{1 . 2 1 2}$ & 4.754 & .007 \\
\hline Error & 5.098 & 20 & .255 & & \\
\hline Total & 5235.405 & 25 & & & \\
\hline Corrected Total & 9.945 & 24 & & & \\
\hline a R Squared $=.487$ (Adjusted R Squared $=.385)$ & & & & \\
\hline
\end{tabular}
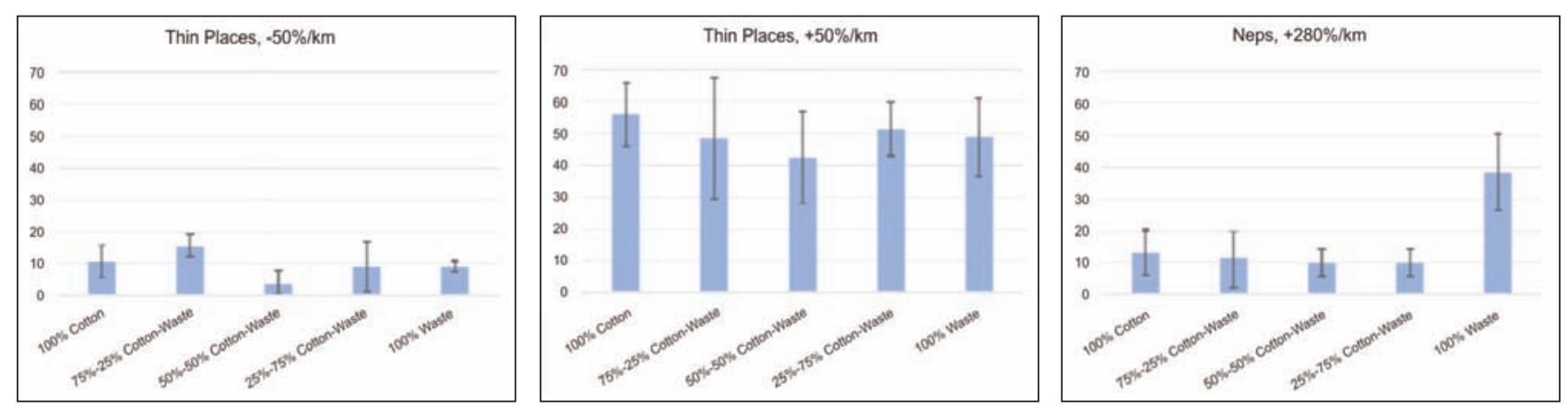

Fig. 2. Imperfections (thin places, thick places and neps) and $95 \%$ confidence intervals 


\begin{tabular}{|c|c|c|c|c|c|c|}
\hline \multicolumn{7}{|c|}{ PAIRWISE COMPARISONS FOR UNEVENNESS (CVM\%) VALUES } \\
\hline \multirow{2}{*}{ (I) Raw } & \multirow{2}{*}{$\begin{array}{l}\text { (J) Raw } \\
\text { Material }\end{array}$} & \multirow{2}{*}{$\begin{array}{c}\text { Mean } \\
\text { Difference } \\
(\mathrm{I}-\mathrm{J})\end{array}$} & \multirow{2}{*}{ Std. Error } & \multirow{2}{*}{ Sig. ${ }^{b}$} & \multicolumn{2}{|c|}{$\begin{array}{l}\text { 95\% Confidence Interval for } \\
\text { Difference }^{\text {b }}\end{array}$} \\
\hline & & & & & Lower bound & Upper bound \\
\hline \multirow[t]{4}{*}{$\% 100$ Cotton } & $\% 25$ Waste & -0.370 & 0.319 & 0.260 & -1.036 & 0.296 \\
\hline & $\% 50$ Waste & -0.350 & 0.319 & 0.286 & -1.016 & 0.316 \\
\hline & $\% 75$ Waste & -0.596 & 0.319 & 0.077 & -1.262 & 0.070 \\
\hline & $\% 100$ Waste & $-1.321^{*}$ & 0.319 & 0.001 & -1.987 & -0.655 \\
\hline \multirow[t]{4}{*}{$\% 25$ Waste } & $\% 100$ Cotton & 0.370 & 0.319 & 0.260 & -0.296 & 1.036 \\
\hline & $\% 50$ Waste & 0.020 & 0.319 & 0.951 & -0.646 & 0.686 \\
\hline & $\% 75$ Waste & -0.226 & 0.319 & 0.487 & -0.892 & 0.440 \\
\hline & $\% 100$ Waste & $-0.951^{*}$ & 0.319 & 0.007 & -1.617 & -0.285 \\
\hline \multirow[t]{4}{*}{$\% 50$ Waste } & $\% 100$ Cotton & 0.350 & 0.319 & 0.286 & -0.316 & 1.016 \\
\hline & $\% 25$ Waste & -0.020 & 0.319 & 0.951 & -0.686 & 0.646 \\
\hline & $\% 75$ Waste & -0.246 & 0.319 & 0.450 & -0.912 & 0.420 \\
\hline & \%100 Waste & $-0.971^{*}$ & 0.319 & 0.006 & -1.637 & -0.305 \\
\hline \multirow[t]{4}{*}{$\% 75$ Waste } & $\% 100$ Cotton & 0.596 & 0.319 & 0.077 & -0.070 & 1.262 \\
\hline & $\% 25$ Waste & 0.226 & 0.319 & 0.487 & -0.440 & 0.892 \\
\hline & $\% 50$ Waste & 0.246 & 0.319 & 0.450 & -0.420 & 0.912 \\
\hline & $\% 100$ Waste & $-0.725^{*}$ & 0.319 & 0.034 & -1.391 & -0.059 \\
\hline \multirow[t]{4}{*}{$\% 100$ Waste } & $\% 100$ Cotton & $1.321^{*}$ & 0.319 & 0.001 & 0.655 & 1.987 \\
\hline & \%25 Waste & $0.951^{*}$ & 0.319 & 0.007 & 0.285 & 1.617 \\
\hline & $\% 50$ Waste & $0.971^{*}$ & 0.319 & 0.006 & 0.305 & 1.637 \\
\hline & $\% 75$ Waste & $0.725^{*}$ & 0.319 & 0.034 & 0.059 & 1.391 \\
\hline \multicolumn{7}{|c|}{ Based on estimated marginal means } \\
\hline \multicolumn{7}{|c|}{${ }^{*}$ The mean difference is significant at the .05 level } \\
\hline${ }^{\mathrm{b}}$ Adjustment & multiple com & ons: Least & nt Diffe & & di. at a a & \\
\hline
\end{tabular}

\section{Hairiness}

Figure 3 demonstrates the hairiness values $(\mathrm{H}$ and $\mathrm{S} 3$ ) of OE-rotor yarns. As it is seen from the figure, $\mathrm{H}$ values increase but $\mathrm{S} 3$ values decrease while the waste cotton proportion increases. The main reason behind this situation should be the difference between measuring principles of $\mathrm{H}$ and $\mathrm{S} 3$ values. $\mathrm{H}$ value is total length of all protruding fibres along the yarn, while $S 3$ value is the count of the fibres longer than $3 \mathrm{~mm}$. The increasing ratio of waste cotton means more amount of shorter fibres take place around the yarn surface, so that $\mathrm{H}$ and $\mathrm{S} 1+2$ values increase. On the other hand, decreasing total staple length cause decreasing S3 value.

\section{Breaking force and elongation}

Figure 4 shows breaking force and breaking elongation values. $100 \%$ waste cotton yarns have the lowest breaking force and elongation values and it is
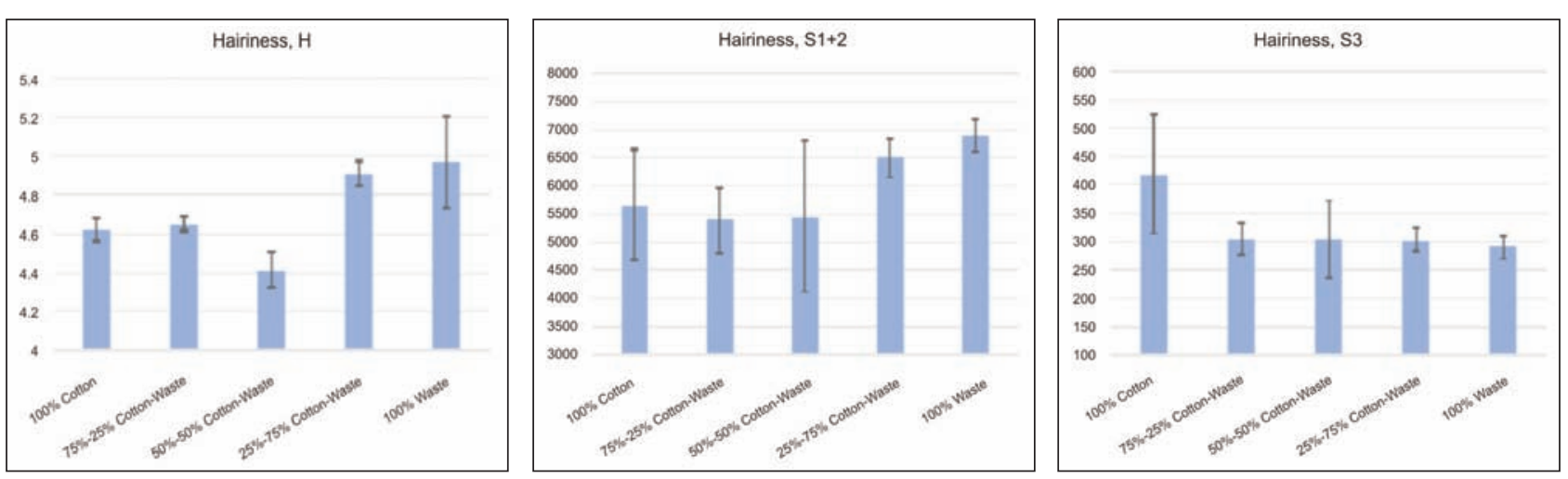

Fig. 3. Hairiness $(H, S 1+2$ and $S 3)$ values and $95 \%$ confidence intervals 

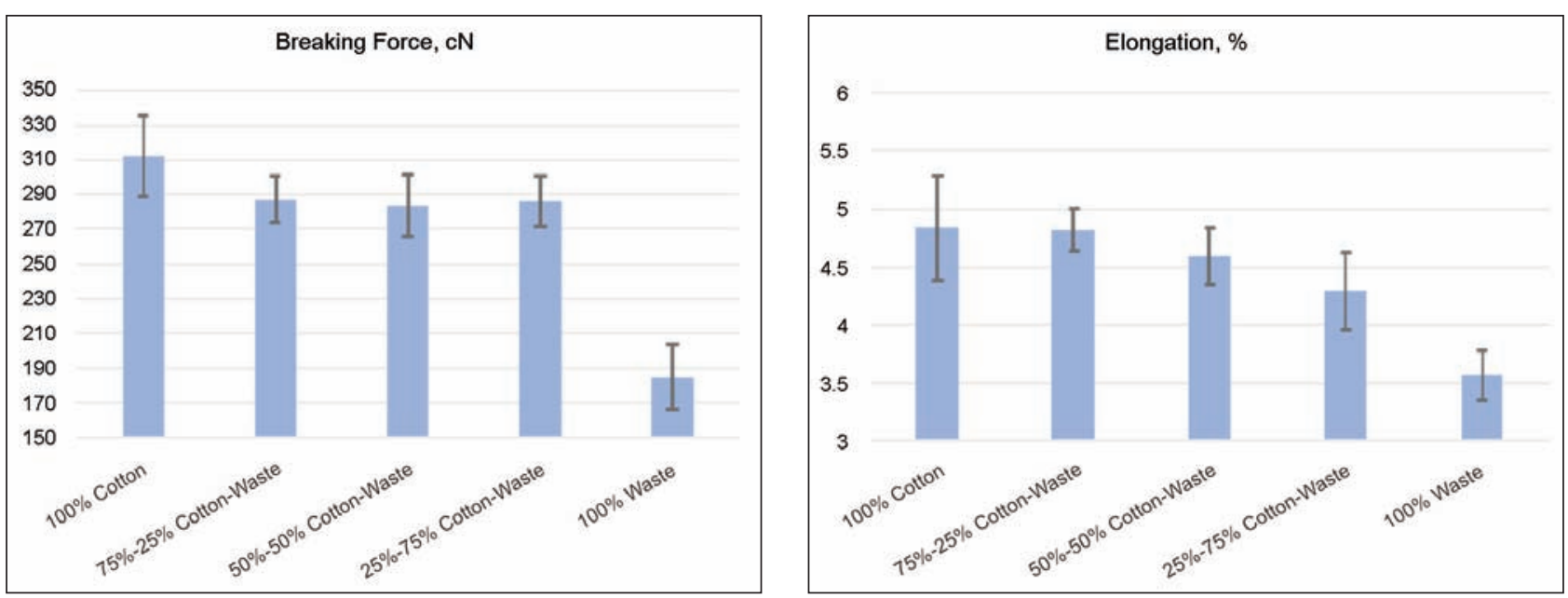

Fig. 4. Breaking force (cN) and breaking elongation (\%) values and 95\% confidence intervals
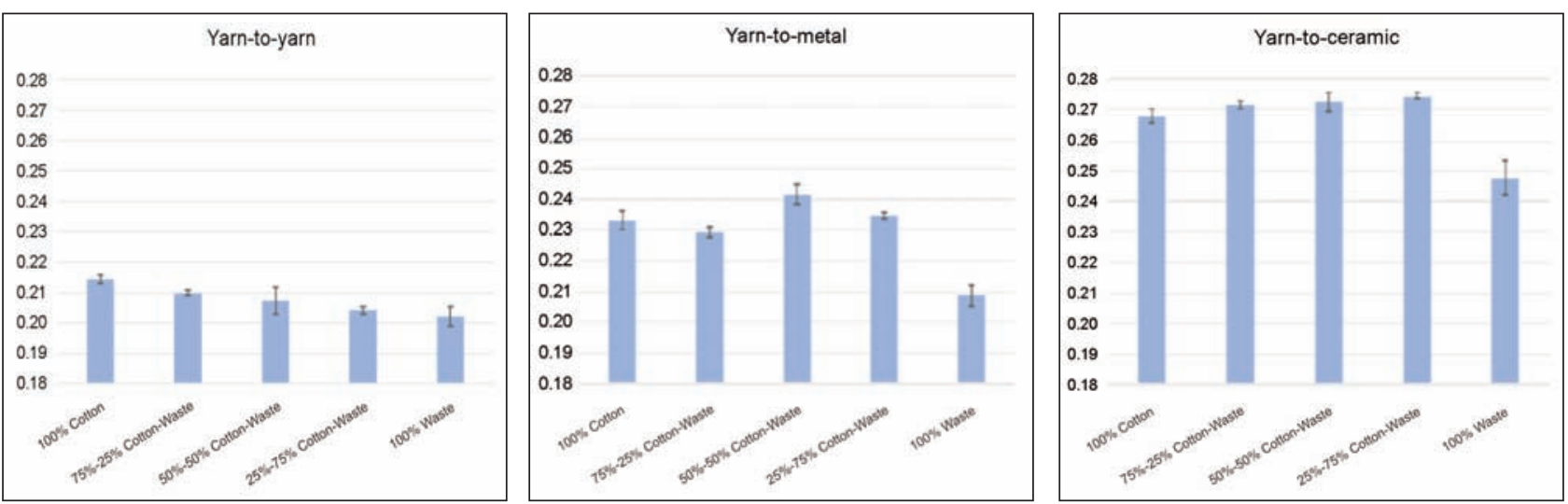

Fig. 5. Friction coefficients and $95 \%$ confidence intervals

related with increasing amount of short fibres create smaller contact surface.

\section{Friction}

Figure 5 shows yarn-to-yarn, yarn-to-metal, yarn-toceramic friction values. The most significant point illustrated by graphs that $100 \%$ waste cotton yarns have the lowest friction values for all surfaces (yarn, metal, ceramic). Friction coefficient is related with yarn hairiness. Because short fibres create a smooth surface, $S 1+2$ values do not cause significant change on friction properties. On the other hand, due to longer fibres might cause stick-slip motion, increasing S3 values give rise to either friction coefficient or output tension.

\section{Evaluation of knitted fabric properties}

\section{Pilling}

Figure 6 illustrates pilling grades of fabrics. Pilling is related with protruding fibre ends, therefore $100 \%$ waste cotton fabrics have the worst pilling values between all fabric types. The other point of view, comparing fabrics produced from blended yarns show that up to $75 \%$ blended ratio does not cause significant change on pilling grade.

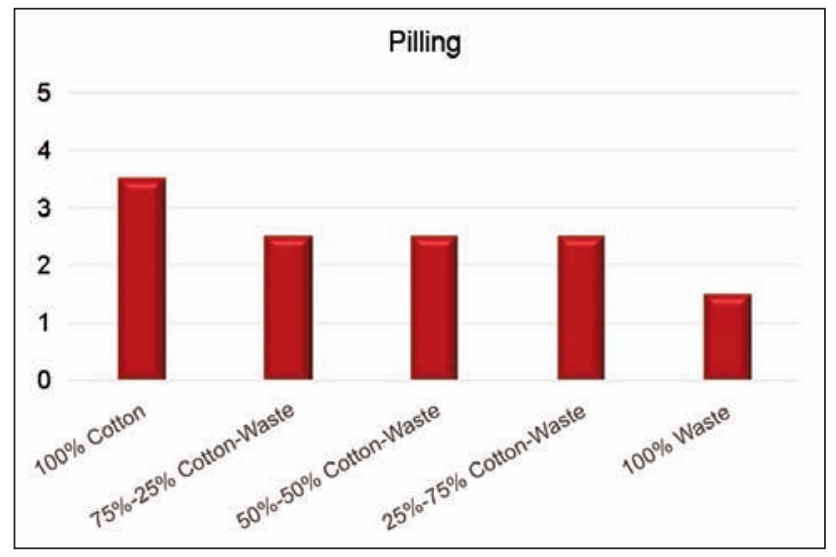

Fig. 6. Pilling ratings

\section{Abrasion resistance}

Figure 7 shows the abrasion resistance results in terms of weight loss (\%) and change in fabric thickness (\%). It can be obtained from the graphs that there is a negative tendency between the waste cotton ratio and abrasion resistance results. However, statistical analysis showed that waste cotton proportion has no significant effect on these values except $100 \%$ waste cotton fabrics. The most probable reason for this situation might be decreasing contact 

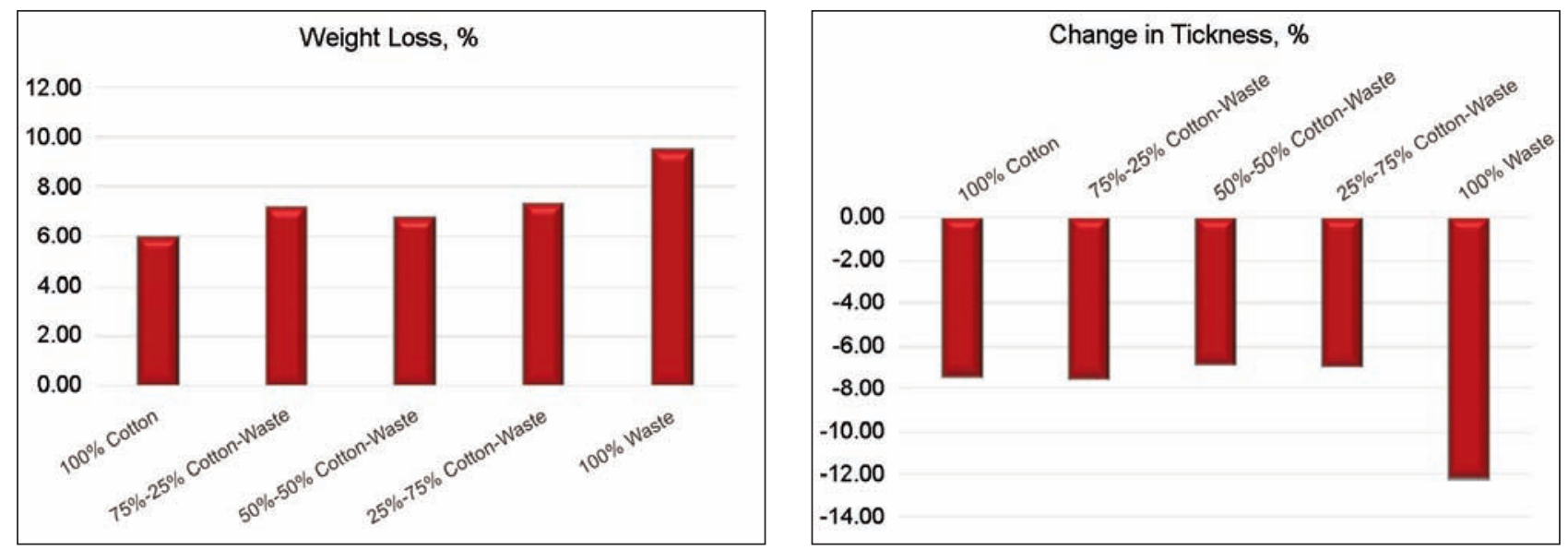

Fig. 7. Weight loss (\%) and change in thickness (\%) after 15000 cycles abrasion test

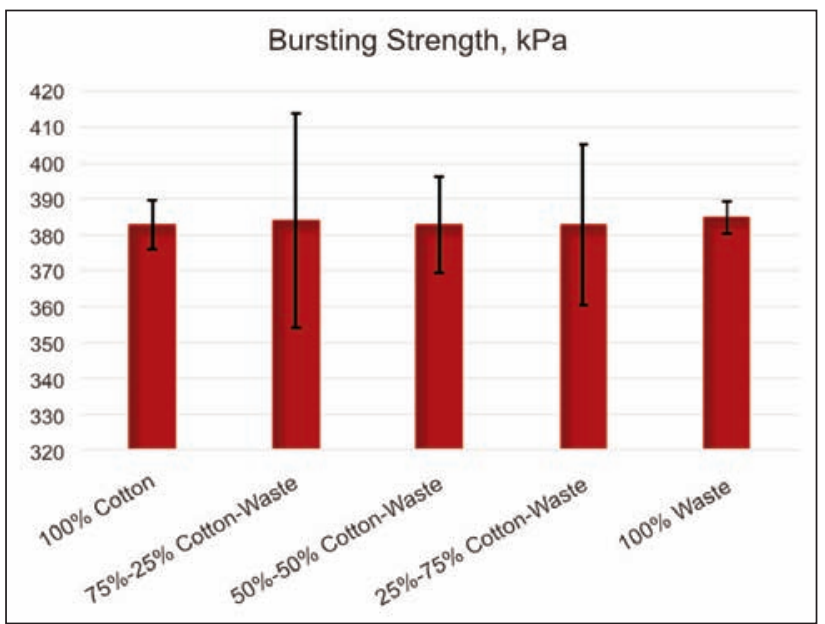

Fig. 8. Bursting strength $(\mathrm{kPa})$ values and $95 \%$ confidence intervals

area between the fibres that causes damage in yarn structure easily after the abrasive movements.

\section{Bursting strength}

Figure 8 illustrates the bursting strength $(\mathrm{kPa})$ results for the fabrics produced from OE-rotor spun blended yarns. Statistical analysis showed that waste cotton proportion has no significant effect on fabric bursting strength.

\section{Air permeability}

Figure 9 shows air permeability values for the produced fabrics. It is clearly seen that air permeability decreases by increasing proportion of waste cotton usage. This situation explained by increasing amount of protruding fibre ends that decrease the fabric porosity.

\section{CONCLUSIONS}

In this study, it was aimed to analyse the effects of cotton waste usage on the properties of yarns and fabrics. For this purpose, OE-rotor yarns made of $100 \%$ virgin cotton, $100 \%$ waste cotton and virgin/waste cotton blends at different proportions (\%25, \%50, \%75) were produced. Moreover, single jersey knitted fabrics were produced from all yarn

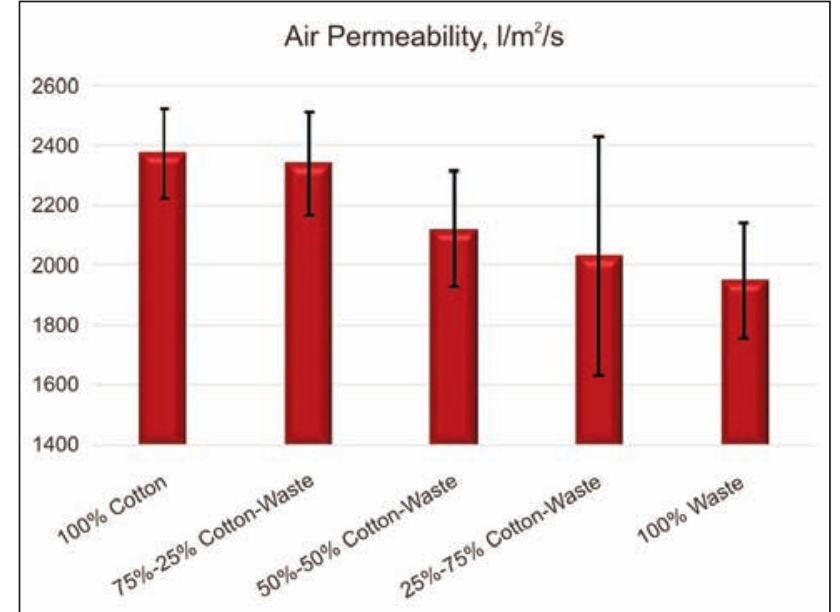

Fig. 9. Air permeability $\left(1 / \mathrm{m}^{2} / \mathrm{s}\right)$ values and $95 \%$ confidence intervals

types. Physical, structural and mechanical properties of all yarn types such as unevenness, imperfections, hairiness, breaking force, elongation, yarn-to-yarn friction, yarn-to-metal friction and yarn-to-ceramic friction were measured. Properties of single jersey knitted fabrics such as pilling, abrasion resistance, bursting strength, air permeability were also evaluated.

Results showed that, as it is expected, yarns and fabrics produced from $100 \%$ virgin cotton have superior results while yarns and fabrics produced from 100\% waste cotton have inferior results in terms of all properties. With respect to the performance properties of yarns and fabrics produced from virgin/waste cotton blends show that using up to $75 \%$ of cotton waste does not cause statistically significant change on the most of yarn and fabric properties. Consequently, it can be concluded that for sustainable, more ecological and economic production process, waste cotton could be used up to $75 \%$ with minor performance reduction of yarn and fabric properties.

\section{ACKNOWLEDGMENT}

This paper was presented in $16^{\text {th }}$ AUTEX, June 8-10, 2016, Ljubljana, SLOVENIA 


\section{BIBLIOGRAPHY}

[1] Wang Y. Recycling in textiles, Woodhead Publishing Limited, Washington, 2006, pp. 1-3.

[2] Shui S., Plastina A. World apparel fiber consumption survey, In: Food and Agriculture Organization of the United Nations and International Cotton Advisory Committee, Washington, 2013, pp. 3-4.

[3] Cotton Incorparated, Cotton Market Fundamentals \& Price Outlook, http://www.cottoninc.com/corporate/MarketData/MonthlyEconomicLetter/, 28.11.2016.

[4] Sule A.D., Bardhan M.K. Recycling of textile waste for environment protection - An overview of some practical cases in the textile industry, In: Indian Journal of Fibre \& Textile Research, 2001, vol. 26, pp. 223-232.

[5] Puma, Puma Recycled Cotton, http://about.puma.com/en/sustainability/products/recycled-cotton, 15.12.2016.

[6] Inditex, Raw Materials, https://www.inditex.com/sustainability/product/raw_material, 02.01.2016.

[7] TNS Political \& Social, Attitudes of Europeans Towards Building the Single Market for Green Products, http://ec.europa.eu/public_opinion/flash/fl_367_sum_en.pdf, 22.01.2013.

[8] Hassani, H., Tabatabaei, S.A., Semnani, D. Determining the optimum spinning conditions to produce the rotor yarns from cotton wastes, In: Industria Textila, 2010, vol. 58, pp. 259-264.

[9] Khan, K.R., Hossain, M.M., Chandra, S.R. Statistical analyses and predicting the properties of cotton/waste blended open-end rotor yarn using Taguchi OA design. In: International Journal of Textile Science, 2015, 4(2), pp. $22-35$.

[10] Taher, H.M., Bechir, A., Mohammed, B.H., Sakli, F. Influence of spinning parameters and recovered fibers from cotton waste on the uniformity and hairiness of rotor spun yarn. In: Journal of Engineered Fibers and Fabrics, 2009, 4(3), pp. 36-45.

[11] Halimi, M.T., Hassen, M.B., Sakli, F. Cotton waste recycling: quantitative and qualitative assessment. In: Resources, Conversation \& Recycling, 2008, vol. 52, pp. 785-791.

[12] Hasssani, H., Tabatabaei, S.A. Optimizing spinning variables to reduce the hairiness of rotor yarns produced from waste fibres collected from the ginning process. In: Fibres \& Textiles in Eastern Europe, 2011, vol. 19, no. 3(86), pp. 21-25.

[13] Halimi, M.T., Hassen, M.B., Azzouz, B., Sakli, F. Effect of cotton waste and spinning parameters on rotor yarn quality. In: The Journal of Textile Institute, 2007, vol. 98, no. 5, pp. 437-442.

[14] Celep, G., Doğan, G., Yüksekkaya, M.E., Tercan, M. An investigation of thermal comfort properties of single jersey fabrics including recycled fibers. In: Düzce University Journal of Science \& Technology, 2015, vol. 4, pp. 104-112.

[15] Vadicherla, T., Saravanan, D. Thermal comfort properties of single jersey fabrics made from recycled polyester and cotton blended yarns, In: Indian Journal of Fibre and Textile Research, 2017, vol. 42, pp. 318-324.

Authors:

MUSA KILIC ${ }^{1}$

H. KÜBRA KAYNAK ${ }^{2}$

GONCA BALCI KILIC ${ }^{1}$

MURAT DEMIR ${ }^{1}$

EFLATUN TIRYAKI ${ }^{2}$

${ }^{1}$ Dokuz Eylül University, Department of Textile Engineering, İzmir, Turkey

${ }^{2}$ Gaziantep University, Department of Textile Engineering, Gaziantep, Turkey

Corresponding author:

MUSA KILIC

e-mail: musa.kilic@deu.edu.tr 